\title{
Megakaryoblast to Total Cell Ratio Measurement
}

National Cancer Institute

\section{Source}

National Cancer Institute. Megakaryoblast to Total Cell Ratio Measurement. NCI

Thesaurus. Code C98753.

The determination of the ratio of megakaryoblasts compared to total cells present in a sample. The measurement may be expressed as a ratio or percentage. 